\title{
Faktor-Faktor yang Mempengaruhi Prokrastinasi Akademik Siswa yang Menjadi Anggota Organisasi Siswa Intra Sekolah
}

\author{
Nafeesa \\ Jurusan Psikologi, Fakultas Psikologi, Universitas Medan Area, Indonesia
}

\begin{abstract}
Abstrak
Fokus artikel ini adalah mengenai faktor-faktor yang mempengaruhi prokratinasi akademik siswa ketika menjadi anggota OSIS. Prokrastinasi menciptakan masalah eksternal, seperti menunda mengerjakan tugas membuat kita tidak dapat mengerjakan tugas dengan baik dan mendapat peringatan dari guru. Prokrastinasi menimbulkan masalah internal, seperti merasa bersalah atau menyesal. Prokrastinasi juga bisa diartikan kecenderungan untuk menunda atau menghindari sepenuhnya tanggung jawab, keputusan, atau tugas yang perlu dilakukan, dan biasanya baru mulai dikerjakan pada saat-saat terakhir batas pengumpulan tugas. Seorang prokrastinator memiliki pandangan bahwa suatu tugas harus diselesaikan dengan sempurna, sehingga dia merasa lebih aman untuk tidak melakukannya dengan segera. Berdasarkan pendapat ahli diatas disimpulkan pengertian prokrastinasi sebagai suatu penundaan yang dilakukan secara sengaja dan berulang-ulang, dengan melakukan aktivitas lain yang tidak diperlukan dalam pengerjaan tugas yang penting. Seseorang yang memiliki kesulitan untuk melakukan sesuatu sesuai dengan batasan waktu yang telah ditentukan, sering mengalami keterlambatan mempersiapkan diri secara berlebihan, maupun gagal dalam menyelesaikan tugas sesuai batas waktu bisa dikatakan sebagai procrastinator. Urutan faktor yang mempengaruhi prokrastinasi akademik pada siswa yang menjadi anggota OSIS yaitu Time Disorganisation, Keadaan Fisik Individu, Karakteristik Tugas, Sikap Dan Keyakinan, Kondisi Psikologis Individu, Anxiety, Dukungan Sosial, Gaya Pengasuhan Orang Tua, Hostility With Other, dan Kondisi Lingkungan.
\end{abstract}

Kata Kunci : Prokrastinasi, Akademik, Siswa

\section{Abstract}

The focus of this article is on the factors that affect student academic procratation when becoming a member of oSIS. Procrastination creates external problems, such as delaying the task makes us unable to do a good job and get warning from the teacher. Procrastination raises internal problems, such as feeling guilty or sorry. Procrastination can also be interpreted as a tendency to delay or completely avoid the responsibilities, decisions, or tasks that need to be done, and usually only begin at the last moment of the task-gathering limit. A procrastinator has the view that a task must be completed perfectly, so that it feels safer not to do it immediately. Based on the opinion of the above experts concluded the notion of procrastination as a deliberate deliberate and repetitive delays, by performing other activities that are not required in the crucial task. A person who has difficulty to do something within the prescribed time limit, often suffers from excessive prepayment, or failure to complete tasks within a time limit can be regarded as a procrastinator. The sequence of factors affecting academic procrastination in students who are members of OSIS are Time Disorganisation, Individual Physical Condition, Task Characteristics, Attitudes and Beliefs, Individual Psychological Conditions, Anxiety, Social Support, Parenting Style, Hostility With Other, and Environmental Conditions.

Keywords: Procrastination, Academic, Student

How to Cite: Nafeesa. (2018). Faktor-Faktor yang Mempengaruhi Prokrastinasi Akademik Siswa yang Menjadi Anggota Organisasi Siswa Intra Sekolah. Anthropos: Jurnal Antropologi Sosial dan Budaya, 4 (1): 53-67,
*Corresponding author:
E-mail: nafeesa@staff.uma.ac.id 


\section{PENDAHULUAN}

Pendidikan merupakan aktivitas yang berlangsung sepanjang hidup manusia. Pendidikan itu sendiri tidak dapat dipisahkan dari istilah belajar karena pada dasarnya belajar merupakan bagian dari pendidikan. Selain itu proses belajar merupakan suatu kegiatan yang pokok atau utama dalam dunia pendidikan. Manusia tidak akan pernah berhenti belajar karena setiap langkah manusia dalam hidupnya akan dihadapkan pada permasalahan yang membutuhkan pemecahan dan menuntut manusia untuk belajar menghadapinya. Belajar merupakan suatu perubahan dari tidak tahu menjadi tahu dari tidak bisa menjadi bisa sehingga proses belajar akan mengarah pada tujuan dari belajar itu sendiri.

Pendidikan merupakan salah satu aspek penting bagi suatu bangsa untuk menunjukkan kualitas, serta memajukan bangsa itu sendiri. Pendidikan pada umumnya dapat dilakukan secara formal dan informal. Sekolah merupakan lingkungan kedua sebagai tempat untuk membina membimbing anak selain dirumah. Individu dapat menerima pengalaman baru serta dapat mengembangkan segala aspek yang dimiliki untuk menjadi lebih baik dan bermanfaat disekolah. Individu yang mengikuti pendidikan formal di sekolah disebut sebagai siswa. Pendidikan formal disekolah memiliki tingkatan mulai dari SD, SMP sampai dengan SMA, individu yang berada pada tingkatan SMA diberikan tugas-tugas yang lebih banyak agar lebih terlatih memecahkan berbagai masalah pelajaran. Kewajiban seorang siswa bukan hanya dalam bidang akademik, akan tetapi ada kewajiban untuk mengikuti organisasi yang disediakan oleh sekolah. Salah satu organisasi resmi di sekolah adalah OSIS. Banyaknya tugas dan kegiatan-kegiatan yang harus dikerjakan menyebabkan seorang siswa melakukan penundaan dalam mengerjakan tugas atau yang sering disebut dengan prokrastinasi akademik.

Berbicara tentang pendidikan semua sudah pasti mengetahui betapa pentingnya hal tersebut. Pendidikan dan pengetahuan merupakan modal yang harus dimiliki untuk hidup di zaman yang serba sulit pada saat ini. Sebagai peserta didik, siswa diharapkan dapat mampu menyelesaikan tugas-tugas sekolah yang merupakan kewajiban yang harus dikerjakan sebagai salah satu syarat untuk mendapat nilai yang baik. Dalam mengerjakan tugas disekolah, siswa diharapkan memiliki waktu dan perencanaan yang baik. Adapun perencanaan ini, sering diganggu dan dipengaruhi oleh beberapa hal seperti kesulitannya mengatur waktu.

Siswa adalah peserta didik yang terdaftar dan belajar di suatu lembaga sekolah tertentu. Siswa SMA dalam tahap perkembangannya digolongkan sebagai masa remaja. Menurut Hurlock (1980), awal masa remaja berlangsung kira-kira dari 13-17 tahun. Masa remaja ditinjau dari rentang kehidupan manusia merupakan masa peralihan dari masa kanak-kanak menuju ke dewasa, dimana tugas perkembangan pada masa remaja menuntut perubahan besar dalam sikap dan pola perilaku anak, akibatnya hanya sedikit anak laki-laki dan anak perempuan yang diharapkan mampu menguasai tugas-tugas tersebut selama awal masa remaja, apalagi mereka yang matangnya terlambat.

Oleh karena itu dalam menjalankan tugas perkembangannya peran serta dari orang tua sangat dibutuhkan terutama dalam belajar atau bidang akademik. Belajar merupakan tugas utama seorang siswa, namun tidak semua siswa memiliki pengelolaan belajar yang baik, khususnya dalam pengelolaan waktu.

Di sekolah terdapat proses belajar mengajar yang merupakan interaksi antara guru dan siswa. Berhasil atau tidaknya pencapaian tujuan pendidikan tersebut tergantung kepada proses belajar yang dialami siswa itu sendiri sebagai anak didik. Agar siswa berhasil, siswa harus mampu memahami materi pelajaran yang nantinya diharapkan siswa dapat menyelesaikan ujian dengan baik sebagai hasil evaluasi belajar. Dalam aktivitas belajar salah satu hal yang dilakukan guru selain menjelaskan materi merupakan memberikan tugas. Tugas tersebut meliputi menjawab soal latihan buatan sendiri, soal dalam buku pegangan, mengerjakan pekerjaan rumah, ulangan harian, ulangan umum, dan ujian.

OSIS adalah kependekan dari Organisasi Siswa Intra Sekolah merupakan organisasi yang berada ditingkat sekolah di Indonesia yang dimulai dari Sekolah Menengah Pertama (SMP) dan Sekolah Menengah Atas (SMA). OSIS diurus dan dikelola oleh murid-murid yang terpilih untuk menjadi pengurus OSIS. Biasanya organisasi ini memiliki seorang pembimbing dari guru yang dipilih oleh 
pihak sekolah. Anggota OSIS adalah seluruh siswa yang berada pada satu sekolah tempat OSIS itu berada. Seluruh anggota OSIS berhak untuk memilih calonnya untuk kemudian menjadi pengurus OSIS.

Berbagai aktivitas yang diikuti oleh dirinya merupakan salah satu penyebab siswa yang mengikuti OSIS melakukan prokrastinasi. Selain dengan berbagai kegiatan atau tugas yang dihadapi oleh mereka, biasanya mereka selalu cenderung tidak memikirkan atau menunda tugas sekolah yang diberikan oleh gurunya. Hal tersebut bisa saja disebabkan oleh mereka yang tidak pandai dalam mengatur waktunya, atau kekelahan karena aktivitas yang sudah dijalankan sebelumnya.

Kesenjangan waktu antara rencana dan kegiatan aktual, maksudnya siswa yang melakukan prokrastinasi mempunyai kesulitan untuk melakukan sesuatu sesuai dengan batas waktu yang telah ditentukan sebelumnya. Seorang prokrastinator sering mengalami keterlambatan dalam memenuhi deadline yang telah ditentukan, baik oleh orang lain maupun rencana-rencana yang telah ditentukan sendiri. Seseorang mungkin telah merencanakan untuk mulai mengerjakan tugas pada waktu yang telah ditentukan akan tetapi ketika saatnya tiba tidak juga melakukannya sesuai dengan apa yang telah direncanakan, sehingga menyebabkan keterlambatan maupun kegagalan untuk menyelesaikan tugas secara memadai dengan melakukan aktivitas lain yang lebih menyenangkan daripada melakukan tugas yang harusnya dikerjakan. Siswa yang melakukan prokrastinasi dengan sengaja tidak segera melakukan tugasnya, akan tetapi menggunakan waktu yang dia miliki untuk melakukan aktivitas lain yang dipandang lebih menyenangkan dan mendatangkan hiburan, seperti membaca (koran, majalah, atau buku cerita lainnya), nonton, ngobrol, jalan, mendengarkan musik, dan sebagainya, sehingga menyita waktu yang dia miliki untuk mengerjakan tugas yang harus diselesaikannya.

Jadi dapat disimpulkan bahwa ciri-ciri prokrastinasi akademik adalah penundaan untuk memulai maupun menyelesaikan kerja pada tugas yang dihadapi, keterlambatan dalam mengerjakan tugas, kesenjangan waktu antara rencana dan kinerja aktual dan melakukan aktivitas lain yang lebih menyenangkan daripada melakukan tugas yang harus dikerjakan.
Melihat perkembangan jaman akhir-akhir ini dibidang teknologi yang semakin canggih membuat anak kehilangan minat dalam belajar. Seringkali orangtua mengeluhkan akan hal ini, memang tidak bisa kita hindarkan perkembangan IPTEK yang terus maju di Indonesia.

Tidak pandainya mengatur waktu merupakan salah satu penyebab siswa menjadi malas mengerjakan tugasnya, mereka lebih senang untuk melakukan hal yang menurut mereka lebih menyenangkan seperti bermain, bercanda, dibandingkan dengan belajar sesuatu untuk menambah pengetahuannya.

Pekerjaan rumah atau (PR) merupakan tugas yang diberikan pada pelajar oleh guru sekolah untuk dikerjakan diluar sekolah. Alasan pemberian pekerjaan rumah adalah untuk meningkatkan pemahaman siswa mengenai materi-materi yang telah diajarkan oleh gurunya. Pekerjaan rumah dipercaya menjadi arti penting bagi kedisiplinnan ingatan murid. Ingatan tidak hanya digunakan sebagai perolehan pengetahuan saja tetapi juga latihan mental individu. Oleh karena itu, Pekerjaan Rumah dianggap sebagai strategi penting dalam pengajaran.

Selama menuntut ilmu di lembaga pendidikan formal, semua pelajar tidak terlepas dari keharusan dalam mengerjakan tugas-tugas bidang studi, guru pasti memberikan tugas dalam batas waktu tertentu. Oleh karena itu, seorang siswa harus memakai rentang waktu 24 jam dengan sebaik-baiknya dalam mengerjakan tugastugas yang diberikan sampai pada waktu pengumpulan tugas bidang studi tersebut.

Dalam pelaksanaan tugas tersebut banyak terjadi hambatan yang disebabkan oleh beberapa hal. Ada hambatan yang berasal dari dalam diri sendiri dan dari luar diri. Salah satunya adalah prokrastinasi. Secara khusus, prokrastinasi yang terjadi pada area akademik disebut prokrastinasi akademik. Prokrastinasi akademik banyak dilakukan oleh pelajar atau mahasiswa. Prokrastinasi adalah menunda dengan sengaja kegiatan yang diinginkan walaupun mengetahui bahwa perilaku penundaannya tersebut dapat menghasilkan dampak yang buruk.

Dalam menempuh jenjang pendidikan, sering terjadi beberapa masalah dan hambatan yang dialami oleh para siswa. Umumnya para siswa sering mengeluh mengenai permasalahan seperti 
ketidaknyamanan dengan kondisi sekolah, cara guru mengajar, tugas yang dianggap terlalu banyak hingga adanya keengganan untuk belajar.

Prokrastinasi atau perilaku menunda penyelesaian suatu tugas terjadi pada setiap orang. Demikian pula yang terjadi pada siswa. Siswa dalam menghadapi tugas-tugas sekolah seringkali muncul rasa malas dan keengganan untuk mengerjakan tugas tersebut, sehingga tugas tidak dapat diselesaikan sesuai dengan batas waktu yang telah ditentukan. Rasa malas dan keengganan untuk mengerjakan tugas tersebut membuat siswa untuk menunda mengejakan tugas-tugas yang seharusnya dikerjakan. Dampak dari prokrastinasi adalah tugas sekolah menjadi terbengkalai dan penyelesaian tidak maksimal berpotensi mengakibatkan kegagalan atau terhambatnya seorang siswa meraih kesuksesan.

Seseorang yang mempunyai kesulitan untuk melakukan sesuatu sesuai batas waktu yang telah ditentukan, sering mengalami keterlambatan, mempersiapkan sesuatu dengan sangat berlebihan, dan gagal dalam menyelesaikan tugas sesuai batas waktu yang telah ditentukan, dikatakan sebagai orang yang melakukan prokrastinasi. Oleh sebab itu, prokrastinasi dapat dikatakan sebagai salah satu perilaku yang tidak efisien dalam menggunakan waktu dan adanya kecenderungan untuk tidak segera memulai suatu pekerjaan ketika menghadapi suatu tugas.

Prokrastinasi dapat dipandang dari berbagai segi. Hal ini dikarenakan prokrastinasi melibatkan berbagai unsur masalah yang kompleks, yang saling terkait satu dengan lainnya. Prokrastinasi dapat dikatakan hanya sebagai suatu penundaan atau kecenderungan menunda-nunda memulai suatu pekerjaan. Namun, prokrastinasi juga dapat dikatakan penghindaran tugas yang diakibatkan karena perasaan tidak senang terhadap tugas dan takut gagal dalam mengerjakan tugas. Prokrastinasi juga bisa sebagai suatu trait atau kebiasaan seseorang terhadap respons dalam mengerjakan tugas.

Menurut Silver seseorang yang melakukan prokrastinasi tidak bermaksud untuk mengindari atau tidak mau tahu dengan tugas yang dihadapi. Akan tetapi mereka hanya menunda-nunda untuk mengerjakannya sehingga menyita waktu yang dibutuhkan untuk menyelesaikan tugas. Ellis dan Knaus mengatakan bahwa prokrastinasi adalah kebiasaan penundaan yang tidak bertujuan dan proses penghindaran tugas yang sebenarnya tidak perlu dilakukan. Hal ini terjadi karena adanya ketakutan untuk gagal dan pandangan bahwa segala sesuatu harus dilakukan dengan benar (dalam Ghufron \& Risnawita, 2010).

Prokrastinasi terjadi pada setiap individu tanpa memandang usia, jenis kelamin atau status sebagai pekerja atau pelajar. Semua individu dari berbagai kalangan, sedikitnya 95\% melakukan prokrastinasi dengan frekuensi kadang dan sekitar 15 s/d 20\% diantaranya melakukan prokrastinasi secara konsisten.

Faktanya, banyak siswa maupun siswi yang menjadi anggota OSIS melakukan prokrastinasi akademik. Perilaku penundaan dalam mengerjakan tugas sekolah atau yang sering disebut dengan prokrastinasi akademik menurut Ghufron \& Risnawita (2010) dipengaruhi oleh faktor-faktor internal maupun eksternal. Faktor internal diantaranya kondisi fisik, kondisi psikologis, dan faktor eksternalnya ialah gaya pengasuhan orangtua dan kondisi lingkungan.

Karakter di sini mencakup kurang percaya diri, moody dan irrasional. Orang yang cenderung menunda pekerjaan jika kurang percaya diri dalam melaksanakan pekerjaan tersebut ia takut terjadi kesalahan. Siswa yang berkarakter moody merupakan orang yang hampir sering menunda pekerjaan. Burka dan Yuen (dalam Ghufron \& Risnawita, 2010) menegaskan kembali dengan menyebutkan adanya aspek irrasional yang dimiliki seorang prokrastinator. Mereka memiliki pandangan bahwa suatu tugas harus diselesaikan dengan sempurna, sehingga dia merasa lebih aman untuk tidak mengerjakannya dengan segera karena itu akan menghasilkan sesuatu yang kurang maksimal.

Prokrastinasi dapat didefinisikan sebagai suatu penundaan yang dilakukan secara sengaja dan berulang-ulang, dengan melakukan aktivitas lain yang tidak diperlukan dalam pengerjaan tugas. Mc Carthy (dalam LaForge, 2005), prokrastinasi adalah kecenderungan untuk menunda atau menghindari sepenuhnya tanggung jawab, keputusan, atau tugas yang perlu dilakukan, dan biasanya baru mulai dikerjakan pada saat-saat terakhir batas pengumpulan tugas. Seorang prokrastinator memiliki pandangan bahwa suatu tugas harus diselesaikan dengan sempurna, 
sehingga dia merasa lebih aman untuk tidak melakukannya dengan segera.

Prokrastinasi pada siswa misalnya kecenderungan untuk menghindari tugas-tugas yang mereka anggap kurang menyenangkan dan menggantinya dengan aktivitas yang lebih menyenangkan. Hal ini mungkin merupakan salah satu cara menghindari dan melarikan dari tanggung jawab atau salah satu bentuk dari kecemasan yang berhubungan dengan pelajaran. Seorang prokrastinator tidak akan melakukan prokrastinasi jika tugas tersebut harus dilakukan dan mereka merasa yakin dengan kemampuannya dalam melaksanakan tugas tersebut. Menunda mungkin tampak lebih menyenangkan daripada meningkatkan kemampuan dalam mengerjakan tugas.

Hasil penelitian di luar negeri menunjukkan bahwa prokrastinasi merupakan salah satu masalah yang menimpa sebagian besar anggota masyarakat secara luas, dan pelajar pada lingkungan yang lebih kecil, seperti sebagian pelajar disana. Sekitar 25\% sampai dengan 75\% dari pelajar melaporkan bahwa prokrastinasi merupakan salah satu masalah dalam lingkup akademis mereka.

\section{PEMBAHASAN}

\section{Pengertian Siswa}

Siswa adalah peserta didik yang terdaftar dan belajar di suatu lembaga sekolah tertentu. Siswa SMA dalam tahap perkembangannya digolongkan sebagai masa remaja. Menurut Hurlock (1980), awal masa remaja berlangsung kira-kira dari 13-17 tahun. Masa remaja ditinjau dari rentang kehidupan manusia merupakan masa peralihan dari masa kanak-kanak menuju ke dewasa, dimana tugas perkembangan pada masa remaja menuntut perubahan besar dalam sikap dan pola perilaku anak, akibatnya hanya sedikit anak laki-laki dan anak perempuan yang diharapkan mampu menguasai tugas-tugas tersebut selama awal masa remaja, apalagi mereka yang matangnya terlambat.

Oleh karena itu dalam menjalankan tugas perkembangannya peran serta dari orang tua sangat dibutuhkan terutama dalam belajar atau bidang akademik. Belajar merupakan tugas utama seorang siswa, namun tidak semua siswa memiliki pengelolaan belajar yang baik, khususnya dalam pengelolaan waktu.

Menurut Djamarah (2002) menyatakan bahwa siswa merupakan bahwa orang yang dengan sengaja datang ke sekolah. Orangtuanyalah yang memasukkan dirinya untuk didik agar menjadi yang berilmu pengetahuan di kemudian hari. Kepercayaan orangtua anak diterima oleh guru dengan kesadaran dan penuh keikhlasan.

Menurut Ursia (2013) menyatakan siswa adalah salah satu kompenen manusiawi yang menempati posisi sentral dalam proses belajar mengajar. Didalam proses belajar mengajar, siswa sebagai pihak yang ingin meraih cita-cita, memiliki tujuan dan kemudian mencapainya secara optimal.

\section{Kebutuhan Siswa}

Menurut Ursia (2013) menyatakan bahwa ada beberapa yang menjadi kebutuhan siswa antara lain:

a) Kebutuhan Jasmaniah

Hal ini berkaitan dengan tujuan siswa yang bersifat jasmaniah, entah yang menyangkut kesehatan jasmani yang dalam hal ini roh raga yang menjadi materi utama. Disamping itu kebutuhankebutuhan lain seperti makan, minum, tidur, pakaian, dan sebagainya, perlu mendapat perhatian.

b) Kebutuhan Sosial

Pemenuhan keinginan untuk saling bergaul sesama siswa dan guru serta orang lain, merupakan salah satu upaya untuk memenuhi kebutuhan sosial anak atau siswa. Dalam hal ini sekolah harus dipandang sebagai lembaga tempat para siswa belajar, bergaul beradaptasi dengan lingkungannya, seperti misalnya bergaul dengan sesama teman yang berbeda jenis kelamin, suku bangsa, agama, status sosial dan kecakapan.

c) Kebutuhan Intelektual

Setiap siswa tidak sama dalam hal minat untuk mempelajari sesuatu ilmu pengetahuan. Mungkin ada yang lebih berminat belajar ekonomi, sejarah, biologi atau yang lain-lain. Minat semacam ini tidak dapat dipaksakan, kalau ingin mencapai hasil belajar yang optimal.

Berdasarkan uraian di atas disimpulkan bahwa kebutuhan siswa didalam belajar mengajar adalah kebutuhan jasmaniah, kebutuhan sosial dan kebutuhan intelektual yang harus dipenuhi dan seimbang sehingga siswa dapat meraih prestasi 
yang diinginkannya apabila kebutuhannya tersebut sudah dipenuhi.

\section{Pengertian Prokrastinasi Akademik}

Istilah prokrastinasi berasal dari bahasa Latin procrastinare, dari kata pro yang artinya maju, ke depan, bergerak maju, dan crastinus yang berarti besok atau menjadi hari esok. Jadi, dari asal katanya prokrastinasi adalah menunda hingga hari esok atau lebih suka melakukan pekerjaannya besok. Orang yang melakukan prokrastinasi dapat disebut sebagai prokrastinator.

Beberapa peneliti berusaha mengajukan definisi yang lebih kompleks tentang perilaku prokrastinasi ini. Steel (dalam Ursia, 2013) mengatakan bahwa prokrastinasi adalah menunda dengan sengaja kegiatan yang diinginkan walaupun individu mengetahui bahwa perilaku penundaannya tersebut dapat menghasilkan dampak buruk.

Milgram, Mey tal dan Levison (dalam Rizki, 2009) mengungkapkan prokrastinasi akademis adalah salah satu tipe prokrastinasi dari lima tipe prokrastinasi yang ada, empat prokrastinasi lainnya adalah prokrastinasi umum atau prokrastinasi rutinitas kehidupan, prokrastinasi dalam membuat keputusan, prokrastinasi neurotis, dan prokrastinasi kompulsif atau disfungsional.

Akinsola, dkk (2007) mendefenisikan prokrastinasi sebagai kecenderungan untuk menunda hal-hal yang seharusnya dilakukan untuk tujuan tertentu. Ghufron \& Risnawita (2010) menyebutkan bahwa seseorang yang mempunyai kesulitan untuk melakukan sesuatu sesuai batas waktu telah ditentukan, sering mengalami keterlambatan, mempersiapkan sesuatu dengan sangat berlebihan dan gagal dalam menyelesaikan tugas sesuai batas waktu yang telah ditentukan, dikatakan sebagai seseorang yang melakukan prokrastinasi sehingga prokrastinasi dikatakan sebagai salah satu perilaku yang tidak efisien dalam penggunaan waktu dan kecenderungan untuk tidak segera memulai pekerjaan ketika menghadapi suatu tugas yang diberikan.

Menurut Fiore (2006) prokrastinasi adalah suatu mekanisme untuk mengatasi kecemasan yang berhubungan dengan bagaimana cara memulai atau menyelesaikan pekerjaan dan dalam hal membuat keputusan. Silver (dalam Ghufron \& Risnawita, 2010) mengatakan bahwa seseorang yang melakukan prokrastinasi tidak bermaksud untuk menghindari atau tidak mau tahu dengan tugas yang dihadapi. Akan tetapi, mereka hanya menunda-nunda untuk mengerjakannya sehingga menyita waktu yang dibutuhkan untuk menyelesaikan tugas. Penundaan tersebut menyebabkan dia gagal menyelesaikan tugasnya tepat waktu.

Akinsola, dkk (2007) mendefinisikan prokrastinasi akademik sebagai bentuk penghindaran dalam mengerjakan tugas yang seharusnya diselesaikan oleh individu. Individu yang melakukan prokrastinasi lebih memilih menghabiskan waktu dengan teman atau pekerjaan lain yang sebenarnya tidak begitu penting daripada mengerjakan tugas yang harus diselesaikan dengan cepat. Selain itu, individu yang melakukan prokrastinasi juga lebih memilih menonton film atau televisi daripada belajar untuk kuis atau ujian.

Sedangkan menurut Ghufron \& Risnawita (2010) mengatakan bahwa prokrastinasi adalah kebiasaan penundaan yang tidak bertujuan dan proses penghindaran tugas yang sebenarnya tidak perlu dilakukan. Hal ini terjadi karena adanya ketakutan untuk gagal dan pandangan bahwa segala sesuatu harus dilakukan dengan benar.

\section{Faktor-Faktor yang Mempengaruhi Prokrastinasi Akademik}

Ghufron \& Risnawita (2010)

mengkategorikan faktor-faktor yang
mempengaruhi prokrastinasi akademik menjadi dua macam, yaitu faktor internal dan faktor eksternal.

\section{Faktor Internal}

Faktor internal adalah faktor-faktor yang terdapat dalam diri individu yang mempengaruhi prokrastinasi. Faktor-faktor itu meliputi kondisi fisik dan kondisi psikologis individu.

a. Kondisi Fisik Individu

Faktor dari dalam diri individu yang turut mempengaruhi munculnya prokrastinasi akademik adalah keadaan fisik dan kondisi kesehatan individu, misalnya fatigue. Seseorang yang mengalami fatigue akan memiliki kecenderungan yang lebih tinggi untuk melakukan prokrastinasi daripada yang tidak. Tingkat inteligensi yang dimiliki seseorang tidak mempengaruhi perilaku prokrastinasi. Walaupun prokrastinasi sering 
disebabkan oleh adanya keyakinan-keyakinan yang irasional yang dimiliki seseorang.

b. Kondisi Psikologis Individu

Menurut Millgram dkk, trait kepribadian individu yang turut mempengaruhi munculnya perilaku penundaan, misalnya trait kemampuan sosial yang tercermin dalam self-regulation dan tingkat kecemasan dalam berhubungan sosial. Besarnya motivasi yang dimiliki seseorang juga akan mempengaruhi prokrastinasi secara negatif. Semakin tinggi motivasi intrinsik yang dimiliki individu ketika menghadapi tugas, akan semakin rendah kecenderungannya untuk melakukan prokrastinasi akademik. Berbagai hasil penelitian juga menemukan aspek-aspek lain pada diri individu yang turut mempengaruhi seseorang untuk mempunyai suatu kecenderungan perilaku prokrastinasi antara lain rendahnya kontrol diri.

\section{Faktor Eksternal}

Faktor eksternal adalah faktor-faktor yang terdapat di luar diri individu yang memengaruhi prokrastinasi. Faktor-faktor itu berupa pengasuhan orangtua dan lingkungan yang kondusif, yaitu lingkungan yang lenient.

a. Gaya Pengasuhan Orangtua

Hasil penelitian Ferrari \& Ollivete menemukan bahwa tingkat pengasuhan otoriter ayah menyebabkan munculnya kecenderungan perilaku prokrastinasi yang kronis pada subjek penelitian anak, sedangkan tingkat pengasuhan demokratis ayah menghasilkan anak yang bukan prokrastinator. Ibu yang memiliki kecenderungan melakukan avoidance procrastination menghasilkan anak yang memiliki kecenderungan untuk melakukan avoidance procrastination pula.

b. Kondisi lingkungan

Kondisi lingkungan yang lanient prokrastinasi akademik lebih banyak dilakukan pada lingkungan yang rendah dalam pengawasan daripada lingkungan yang penuh pengawasan. Tingkat atau level sekolah, juga apakah sekolah terletak di desa ataupun di kota tidak mempengaruhi perilaku prokrastinasi seseorang.

Rizki (2009) mengemukakan faktor-faktor yang mempengaruhi prokrastinasi akademik dapat dikategorikan menjadi tiga macam. Faktor-faktor tersebut adalah:

a. Karakteristik tugas yang dipersepsikan mahasiswa sebagai tugas yang menyenangkan atau membosankan mempengaruhi mahasiswa untuk menunda penyelesaian tugas. Karakteristik tugas yang membosankan pada umumnya membuat mahasiswa melakukan penundaan terhadap suatu tugas.

b. Faktor kepribadian prokrastinator. Individu yang memiliki kepercayaan diri yang rendah akan lebih cenderung melakukan prokrastinasi.

c. Pengaruh faktor situasional, gangguan atau distraksi lingkungan mempengaruhi seseorang untuk menunda pekerjaannya.

Menurut Mustakim (2015) faktor-faktor yang dapat mempengaruhi prokrastinasi akademik adalah:

a. Locus Of Control, diartikan sebagai kemampuan untuk menyusun, membimbing, mengatur dan mengarahkan bentuk perilaku yang dapat membawa ke arah konsekuensi positif.

b. Faktor Dukungan Sosial, merupakan salah satu bentuk dorongan yang dilakukan oleh lingkungan sosial dalam bentuk nasihat verbal atau nonverbal yang memberikan manfaat emosional atau efek perilaku bagi individu sebagai mahluk sosial.

c. Faktor Kepribadian, dapat didefiniskan sebagai suatu bentuk dari sifat-sifat yang ada pada diri individu yang sangat menentukan perilakunya. Kepribadian siswa akan mempengaruhi persepsi dan pengambilan keputusan untuk melakukan prokrastinasi atau tidak.

d. Faktor Perfectionisme, merupakan salah satu aktualisasi diri ideal yang memiliki 3 aspek, yaitu pencarian keagungan neurotik, penuntut yang neurotik, dan kebanggaan neurotik, atau tidak menerima sesuatu yang belum sempurna.

Faktor Sikap dan Keyakinan, dapat didefinisikan sebagai suatu penilaian kognitif seseorang terhadap suka atau tidak suka, perasaan emosional yang tindakannya cenderung kearah berbagai objek atau ide. Sikap sangat mempengaruhi keyakinan begitu pula sebaliknya, keyakinan menentukan sikap. Dalam hubungannya dengan perilaku prokrastinasi akademik, sikap dan keyakinan sangat berpengaruh dalam menentukan suatu perilaku.

Faktor Motivasi Berprestasi, sebagai dorongan yang dimiliki oleh seseorang untuk mengatasi hambatan dalam mencapai tujuan, sehingga individu yang memiliki motivasi berprestasi tinggi menunjukkan usaha yang lebih besar dan ulet. 
Catrunada (2008), yang mengungkapkan tentang sepuluh wilayah magnetis yang menjadi faktor-faktor dilakukannya prokrastinasi:

a. Anxiety, dapat diartikan sebagai kecemasan. Kecemasan pada akhirnya menjadi kekuatan magnetic yang berlawanan dimana tugas-tugas yang diharapkan dapat diselesaikan berinteraksi dengan kecemasan yang tinggi, sehingga seseorang cenderung menunda tugas tersebut.

b. Self-Depreciation, dapat diartikan sebagai pencelaan diri sendiri. Seseorang memilki penghargaan yang rendah atas dirinya sendiri dan selalu siap untuk menyalakan dirinya sendiri ketika terjadi kesalahan dan juga merasa tidak percaya diri untuk mendapat masa depan yang cerah.

c. Low Discomfort Tolerance, dapat diartikan sebagai rendahnya toleransi terhadap ketidaknyaman. Adanya kesulitan pada tugas yang dikerjakan membuat seseorang mengalami kesulitan untuk menoleransi rasa frustasi dan kecemasan, sehingga mereka mengalihkan diri sendiri kepada tugas-tugas yang mengurangi ketidaknyamanan dalam diri mereka.

d. Pleasure-Seeking, dapat diartikan sebagai pencari kesenangan. Seseorang yang mencari kenyamanan cenderung tidak mau melepaskan situasi yang membuat nyaman tersebut. Jika seseorang mimiliki kecenderungan tinggi dalam mencari situasi yang nyaman, maka orang tersebut akan memiliki hasrat yang kuat untuk bersenang-senang dan memiliki control implus yang rendah.

e. Time Disorganization, dapat diartikan sebagai tidak teraturnya waktu. Mengatur waktu berarti bisa mempekirakan dengan baik berapa lama seseorang membutuhkan waktu untuk menyelesaikan pekerjaan tersebut. Aspek lain dari lemahnya pengaturan waktu adalah sulitnya seseorang memutuskan pekerjaan penting dan kurang penting untuk dikerjakan hari ini. Semua pekerjaan terlihat sangat penting sehingga muncul kesulitan untuk menentukan apa yang dikerjakan terlebih dahulu.

f. Enviromental Disorganization, dapat diartikan sebagai berantakan atau tidak teraturnya lingkungan. Salah satu faktor prokrastinasi adalah penyataan bahwa lingkungannya berantakan atau tidak teratur dengan baik hal itu terjadi kemungkinan karena kesalahan individu tersebut. Tidak teraturnya lingkungan bisa dalam bentuk interupsi dari orang lain, kurangnya privasi, kertas yang bertebaran dimana-mana, dan alat-alat yang dibutuhkan dalam pekerjaan tersebut tidak tersedia. Adanya begitu banyak gangguan pada areal pekerjaan menyulitkan seseorang untuk berkonsentrasi sehingga pekerjaan tersebut tidak bisa diselesaikan tepat pada waktunya.

g. Poor Task Approach, dapat diartikan sebagai pendekatan yang lemah terhadap tugas. Jika akhirnya seseorang merasa siap untuk bekerja, kemungkinan dia akan meletakkan kembali pekerjaan tersebut karena tidak tahu dari mana harus memulai sehingga cenderung menjadi tertahan oleh ketidaktahuan tentang bagaimana harus memulai dan menyelesaikan pekerjaan tersebut.

h. Lack of Assertion, dapat diartikan sebagai kurangnya memberikan pernyataan yang tegas. Contohnya adalah seseorang yang mengalami kesulitan untuk berkata tidak terhadap permintaan yang ditujukan kepadanya. Sedangkan banyak hal yang harus dikerjakan karena telah dijadwalkan terlebih dahulu. Hal ini bisa terjadi karena mereka kurang memberikan kehormatan atas semua komitmen dan tanggung jawab yang dimiliki.

i. Hostility With Others, dapat diartikan sebagai permusuhan terhadap orang lain. Kemarahan terus menerus dapat menimbulkan dendam sikap bermusuhan sehingga bisa nenuju sikap menolak atau menentang apapun yang dikatakan orang tersebut.

j. Stress and Fatigue, dapat diartikan sebagai rasa tertekan dan kelelahan. Stres adalah hasil dari sejumlah intensitas tuntutan negatif dalam hidup yang digabung dalam gaya hidup dan kemampuan mengatasi masalah pada diri individu. Semakin banyak tuntutan dan semakin lemah sikap seseorang dalam memecahkan masalah, dan gaya hidup yang kurang baik, semakin tinggi stres seseorang.

k. Berdasarkan pendapat ahli di atas disimpulkan bahwa faktor-faktor yang mempengaruhi prokrastinasi adalah faktor internal yang meliputi kondisi fisik, kondisi psikologis, tidak 
percaya diri, kecemasan, dan sulit mengatur waktu. Faktor eksternal meliputi gaya pengasuhan orangtua, kondisi lingkungan, karakteristik tugas, dukungan sosial dan hostility with other.

\section{Ciri-Ciri Prokrastinasi Akademik}

Ferrari dkk. (1995) mengatakan bahwa sebagai suatu penundaan, prokrastinasi akademik dapat termanifestasikan dalam indikator tertentu yang dapat diukur dan diamati ciri-ciri tertentu. Berikut ini adalah keterangannya.

Penundaan untuk memulai dan menyelesaikan tugas, seseorang yang melakukan prokrastinasi tahu bahwa tugas yang dihadapi harus segera diselesaikan. Akan tetapi, dia menunda-nunda untuk mulai mengerjakannya atau menunda-nunda untuk menyelesaikan sampai tuntas jika dia sudah mulai mengerjakan sebelumnya.

Keterlambatan dalam mengerjakan tugas, orang yang melakukan prokrastinasi memerlukan waktu yang lebih lama daripada waktu yang dibutuhkan pada umumnya dalam mengerjakan suatu tugas. Seorang prokrastinator menghabiskan waktu yang dimilikinya untuk mempersiapkan diri secara berlebihan. Selain itu, juga melakukan halhal yang tidak dibutuhkan dalam penyelesaian suatu tugas, tanpa memperhitungkan keterbatasan waktu yang dimilikinya. Kadang-kadang tindakan tersebut mengakibatkan seseorang tidak berhasil menyelesaikan tugasnya secara memadai. Keterlambatan, dalam arti lambannya kerja seseorang dalam melakukan suatu tugas dapat menjadi ciri yang utama dalam prokrastinasi akademik.

Kesenjangan waktu antara rencana dan kinerja actual, seorang prokrastinator mempunyai kesulitan untuk melakukan sesuatu sesuai dengan batas waktu yang telah ditentukan sebelumnya. Seorang prokrastinator sering mengalami keterlambatan dalam memenuhi deadline yang telah ditentukan, baik oleh orang lain maupun rencana yang telah dia tentukan sendiri. Seseorang mungkin telah merencanakan mulai mengerjakan tugas pada waktu yang telah ia tentukan sendiri. Akan tetapi, ketika saatnya tiba dia tidak juga melakukannya sesuai dengan apa yang telah direncanakan sehingga menyebabkan keterlambatan ataupun kegagalan untuk menyelesaikan tugas secara memadai.

$$
\text { Melakukan aktivitas yang lebih }
$$

menyenangkan, daripada melakukan tugas yang harus dikerjakan. Seorang prokrastinator dengan sengaja tidak segera melakukan tugasnya. Akan tetapi, menggunakan waktu yang dia miliki untuk melakukan aktivitas lain yang dipandang lebih menyenangkan dan mendatangkan hiburan, seperti membaca (Koran, majalah, atau buku cerita lainnya), nonton, ngobrol, jalan, mendengarkan musik, dan sebagainya sehingga menyita waktu yang dia miliki untuk mengerjakan tugas yang harus diselesaikannya.

Dapat disimpulkan bahwa ciri-ciri prokrastinasi akademik adalah penundaan untuk memulai menyelesaikan tugas, keterlambatan dalam mengerjakan tugas, kesenjangan waktu antara rencana dan kinerja aktual, dan melakukan aktivitas yang lebih menyenangkan.

\section{Jenis-Jenis dari Prokrastinasi Akademik}

Ferrari (1995) membagi prokrastinasi menjadi dua, yaitu:

a. Functional Procrastination, yaitu penundaan mengerjakan tugas yang bertujuan untuk memperoleh informasi yang lebih lengkap dan akurat.

b. Disfunctional Procrastination, yaitu penundaan yang tidak bertujuan, berakibat jelek, dan menimbulkan masalah. Ada dua bentuk prokrastinasi yang disfunctional procrastination berdasarkan tujuan mereka melakukan penundaan, yaitu desicional procrastination dan avoidance procrastination.

c. Desicional procrastination adalah suatu penundaan dalam mengambil keputusan. Bentuk prokrastinasi ini merupakan sebuah anteseden kognitif dalam menunda untuk mulai melakukan suatu pekerjaan pada menghadapi situasi yang dipersepsikan penuh stres.

d. Prokrastinasi dilakukan sebagai suatu bentuk coping yang digunakan untuk menyesuaikan diri dalam perbuatan keputusan pada situasisituasi yang dipersepsikan penuh stres. Jenis prokrastinasi ini terjadi akibat kegagalan dalam mengidentifikasikan tugas, yang kemudian menimbulkan konflik dalam diri individu, sehingga akhirnya seorang menunda 
untuk memutuskan masalah. Desicional procrastination ini berhubungan dengan kelupaan dan kegagalan proses kognitif. Akan tetapi tidak berkaitan dengan kurangnya tingkat inteligensi seseorang.

e. Pada avoidance procrastination atau behavioral procrastination adalah suatu penundaan dalam perilaku tampak. Penundaan dilakuakn sebagai suatu cara untuk menghindari tugas yang dirasa tidak menyenangkan dan sulit dilakukan. Prokrastinasi dilakukan untuk menghindari kegagalan dalam menyelesaikan pekerjaan yang akan mendatang. Avoidance procrastination berhubungan dengan tipe self presentation, keinginan untuk menjauhkan diri dari tugas yang menantang, dan impulsiveness.

Berdasarkan pendapat ahli di atas, dapat disimpulkan bahwa jenis-jenis tugas pada prokrastinasi akademik adalah penundaan yang bertujuan untuk memperoleh informasi yang lebih lengkap dan penundaan yang tidak bertujuan, berakibat jelek juga menimbulkan masalah.

\section{Area pada Prokrastinasi Akademik}

Solomon (1984) menyebutkan enam area akademik untuk melihat jenis-jenis tugas yang sering diprokrastinasi oleh pelajar, yaitu:

a. Tugas mengarang, meliputi penundaan melaksanakan kewajiban atau tugas-tugas menulis, misalnya menulis makalah, laporan, atau tugas mengarang lainnya.

b. Belajar menghadapi ujian, mencakup penundaan belajar untuk menghadapi ujian mencakup penundaan belajar untuk menghadapi ujian, misalnya ujian tengah semester, akhir semester, atau ulangan mingguan.

c. Membaca, meliputi adanya penundaan untuk membaca buku atau referensi yang berkaitan dengan tugas akademik yang diwajibkan.

d. Kinerja administrative, seperti menyalin catatan, mendaftarkan diri dalam presensi kehadiran, daftar peserta praktikum, dan sebagainya.

e. Menghadiri pertemuan, yaitu penundaan maupun keterlambatan dalam menghadiri pelajaran, praktikum, dan pertemuanpertemuan lainnya. f. Kinerja akademik secara keseluruhan, yaitu menunda mengerjakan atau menyelesaikan tugas-tugas akademik secara keseluruhan.

\section{Dampak Prokrastinasi Akademik}

Menurut Ursia (2013) prokrastinasi akademik memberikan dampak yang negatif bagi para siswa, yaitu banyaknya waktu yang terbuang tanpa menghasilkan sesuatu yang berguna. Selain itu Tice dan Baumesteir (1997) mengatakan bahwa prokrastinasi dapat menyebabkan stres dan memberikan pengaruh pada disfungsi psikologis individu. Individu yang melakukan prokrastinasi akan menghadapi deadline dan hal ini dapat menjadi tekanan bagi mereka sehingga menimbulkan stres.

\section{Aspek-Aspek Prokrastinasi Akademik}

Mustakim (2015) aspek-aspek prokrastinasi akademik terdiri dari 4 hal antara lain:

a. Perceived time, seseorang yang cenderung prokrastinasi adalah orang-orang yang gagal menepati deadline. Mereka berorientasi pada masa sekarang dan tidak mempertimbangkan masa mendatang. Prokrastinator tahu bahwa tugas yang dihadapinya harus segera diselesaikan, tetapi ia menunda-nunda untuk mengerjakannya atau menunda menyelesaikannya jika ia sudah memulai pekerjaannya tersebut. Hal ini mengakibatkan individu tersebut gagal memprediksikan waktu yang dibutuhkan untuk mengerjakan tugas.

b. Intention-action, celah antara keinginan dan tindakan. Perbedaan antara keinginan dengan tindakan senyatanya ini terwujud pada kegagalan siswa dalam mengerjakan tugas akademik walaupun siswa tersebut punya keinginan untuk mengerjakannya. Ini terkait pula dengan kesenjangan waktu antara rencana dan kinerja aktual. Prokrastinator mempunyai kesulitan untuk melakukan sesuatu sesuai dengan batas waktu. Seorang siswa mungkin telah merencanakan untuk mulai mengerjakan tugasnya pada waktu yang telah ia tentukan sendiri, akan tetapi saat waktunya sudah tiba dia tidak juga melakukan sesuatu sesuai dengan apa yang ia rencanakan sehingga menyebabkan keterlambatan atau bahkan kegagalan dalam menyelesaikan tugas secara memadai. 
c. Emotional distress, adanya perasaan cemas saat melakukan prokrastinasi. Perilaku menundanunda akan membawa perasaan tidak nyaman pada pelakunya, konsekuensi negatif yang ditimbulkan memicu kecemasan dalam diri pelaku prokrastinasi. Pada mulanya siswa tenang karena merasa waktu yang tersedia masih banyak, tanpa rasa resah waktu sudah hampir habis, ini menjadikan mereka merasa cemas karena belum menyelesaikan tugas.

d. Perceived ability, atau keyakinan terhadap kemampuan sendiri. Walaupun prokrastinasi tidak berhubungan dengan kemampuan kognitif seseorang, namun keragu-raguan terhadap kemampuan dirinya dapat menyebabkan seseorang melakukan prokrastinasi. Hal ini ditambah dengan rasa takut akan gagal menyebabkan seseorang menyalahkan dirinya sebagai yang tidak mampu, untuk menghindari munculnya dua perasaan tersebut maka seseorang dapat menghindari tugas-tugas sekolah karena takut akan pengalaman kegagalan.

Dapat disimpulkan bahwa aspek-aspek prokrastinasi akademik adalah seseorang yang gagal menepati deadline, memiliki celah antara keinginan dengan tindakan, perasaan cemas saat melakukan prokrastinasi dan ragu akan kemampuan dirinya sendiri.

Faktor utama yang menyebabkan siswa yang mengikuti OSIS melakukan prokrastinasi dalam melaksanakan tugas sekolahnya yaitu

\section{Time Disorganisation,}

Time disorganisation merupakan salah satu faktor internal yang mempengaruhi siswa yang mengikuti kegiatan OSIS dalam melakukan prokrastinasi Akademiknya. Hal ini sesuai dengan teori yang dikemukakan oleh (Catrunada, 2008) yang menyatakan bahwa aspek lain dari lemahnya pengaturan waktu adalah sulitnya seseoarang memutuskan pekerjaan penting dan kurang penting untuk dikerjakan dihari ini. Semua pekerjaan terlihat sangat penting sehingga muncul kesulitan untuk menetukan apa yang dikerjakan terlebih dahulu.

Hal tersebut dikarenakan terjadi kesenjangan waktu antara rencana dan aktualisasainya. Siswa tersebut sudah melakukan perencanaan untuk mulai mengerjakan tugasanya pada waktu yang telah ia tentukan, namun siswa yang mengikuti OSIS di sekolah tersebut mengatakan bahwa mereka bingung dalam menentukan waktu terhadap apa yang akan dilakukannya terlebih dahulu, selain mereka harus menyiapkan tugas dari sekolahnya (PR), mereka juga disibukkan dengan tugas yang harus dilakukan untuk kegiatan OSISnya. Selain dengan tugas tersebut, mereka juga disibukkan dengan jadwal rapat yang wajib mereka hadiri setelah selesai pulang sekolah, dan ada juga yang harus mengikuti kursus (les) di luar sekolah, sehingga mereka tidak dapat mengatur waktu untuk apa yang harus mereka kerjakan duluan. Ketidakteraturan waktu yang dimiliki oleh siswa yang mengikuti kegiatan OSIS cenderung akan melakukan prokrastinasi.

\section{Keadaan Fisik Individu.}

Faktor kedua yang menyebabkan siswa yang mengikuti OSIS melakukan prokrastinasi dalam melaksanakan tugas sekolahnya yaitu Keadaan Fisik Individu. Keadaan fisik individu merupakan faktor eksternal yang mempengaruhi siswa yang mengikuti kegiatan OSIS dalam melakukan prokrastinasi Akademiknya. Hal ini sejalan dengan teori (Ghufron \& Risnawita, 2010) yang menyatakan bahwa seseorang yang mengalami fatigue akan memiliki kecenderungan yang lebih tinggi untuk melakukan prokrastinasi.

Hal tersebut dikarenakan siswa yang mengikuti kegiatan OSIS di sekolah tersebut selain disibukkan dengan tugas yang harus mereka kerjakan, juga mereka harus mengerjakan kegiatan OSIS yang dikutinya mulai dari perkumpulan harian dan rencana kegiatan OSIS tersebut setelah pulang jam sekolah. Selain itu, mereka juga ada yang harus mengikuti kursus (les tambahan) di luar sekolah. Setelah mereka selesai melakukan tersebut, mereka merasa kelelahan dan memutuskan untuk melakukan istirahat atau tidur dibandingkan mengerjakan tugas sekolah yang membuat pikiran mereka makin lelah.

\section{Karakteristik Tugas}

Faktor ketiga yang menyebabkan siswa yang mengikuti OSIS melakukan prokrastinasi dalam melaksanakan tugas sekolahnya yaitu Karakteristik Tugas. Karakteristik Tugas merupakan faktor eksternal yang mempengaruhi siswa yang mengikuti kegiatan OSIS dalam melakukan prokrastinasi Akademiknya. Hal tersebut sesuai dengan (Rizki, 2009), yang menyatakan bahwa karakteristik tugas yang membosankan pada 
umumnya membuat mahasiswa cenderung melakukan penundaan terhadap suatu tugas.

Tugas yang mereka anggap susah, cenderung akan diabaikan oleh responden karena mereka beranggapan hal tersebut akan mudah dikerjakan oleh siswa yang tidak mengikuti kegiatan Osis di sekolah tersebut. Mereka beranggapan bahwa tugas yang susah cenderung makin melelahkan pikiran mereka sehingga memutuskan untuk melakukan prokrastinasi. Tetapi sebaliknya, apabila tugas tersebut dianggap mudah, mereka mau mengerjakannya secara berkelompok. Selain itu, dengan tugas yang sulit diberikan oleh gurunya cenderung mereka untuk takut salah dalam pengerjaannya hingga menyebabkan kecemasan dari dalam diri mereka dan sampai menimbulkan prokrastinasi. Di samping itu, jumlah tugas yang diberikan gurunya kepada siswa yang mengikuti kegiatan OSIS telalu banyak, cenderung siswa akan menunda akan melakukan prokrastinasi.

\section{Sikap dan Keyakinan}

Faktor keempat yang menyebabkan siswa yang mengikuti OSIS melakukan prokrastinasi dalam melaksanakan tugas sekolahnya yaitu Sikap dan Keyakinan. Sikap dan keyakinan merupakan faktor internal yang mempengaruhi siswa yang mengikuti kegiatan OSIS dalam melakukan prokrastinasi Akademiknya. Hal tersebut sesuai dengan (Mustakim, 2015) yang menyatakan bahwa sikap dapat didefinisikan sebagai suatu penilaian kognitif seseorang terhadap suka atau tidak suka, perasaan emosional yang tindakannya cenderung berbagai objek atau ide yang sangat berpengaruh dalam menentukan suatu perilaku.

Sikap dan keyakinan yang dimaksudkan yaitu bagaimana cara siswa memandang terhadap tugas mata pelajaran yang diberikan oleh gurunya. Siswa yang mengikuti OSIS pasti memiliki mata pelajaran yang berbeda untuk disukai. Bagi siswa disana, apabila tugas sekolah yang diberikan merupakan mata pelajaran yang mereka sukai cenderung mereka akan mengerjakan tugas tersebut. Begitu sebaliknya, apabila tugas sekolah yang diberikan merupakan mata pelajaran yang tidak mereka sukai cenderung mereka akan melakukan prokrastinasi. Selain itu, siswa yang mengikuti kegiatatan OSIS cenderung tidak memiliki keyakinan dalam mengerjakan tugas yang diberikan oleh gurunya sehingga menimbulkan rasa ketidakpercayaan pada dirinya dan terjadilah prokrastinasi akademiknya.

\section{Keadaan Psikologis Individu}

Faktor kelima yang menyebabkan siswa yang mengikuti OSIS melakukan prokrastinasi dalam melaksanakan tugas sekolahnya yaitu Keadaan Psikologis Individu. Keadaan psikologis individumerupakan faktor internal yang mempengaruhi siswa yang mengikuti kegiatan OSIS dalam melakukan prokrastinasi Akademiknya. Hal ini sesuai dengan pernyataan (Ghufron \& Risnawita, 2010) yang menyatakan bahwa semakin besarnya motivasi yang dimiliki individu ketika menghadapi tugas, akan semakin rendahnya kecenderungan untuk melakukan prokrastinasi akademiknya.

Hal tersebut dikarenakan mereka tidak memiliki motivasi, semangat, serta kontrol diri yang kuat dalam mengerjakan tugas mereka. Selain itu, mereka memiliki keraguan terhadap kemampuan dirinya ditambah dengan rasa takut akan gagal menyebabkan diri mereka sebagai yang tidak mampu. Setelah melakukan aktivitasnya disekolah cenderung mereka merasa kurang semangat dan tidak memiliki motivasi dari dalam dirinya sendiri untuk mengerjakan tugas yang diberikan oleh gurunya. Bagi mereka, tugas tersebut membuat pikiran mereka semakin merasa kelelahan setelah pulang dari kegiatan sekolahnya. Di samping itu, tidak adanya kontrol dari dalam dirinya membuat siswa yang mengikuti kegiatan OSIS menjadi tidak bisa mengendalikan antara kegiatan istitrahat atau menyelesaikan tugas yang telah diberikan.

\section{Anxiety}

Faktor keenam yang menyebabkan siswa yang mengikuti OSIS melakukan prokrastinasi dalam melaksanakan tugas sekolahnya yaitu Anxiety. Anxiety merupakan faktor internal yang mempengaruhi siswa yang mengikuti kegiatan OSIS dalam melakukan prokrastinasi Akademiknya. Sesuai dengan pernyataan (Catrunada, 2008) yang menyatakan bahwa kecemasan pada akhirnya menjadi kekuatan magnetik yang berlawanan dimana tugas - tugas yang diharapkan dapat diselesaikan berinteraksi dengan kecemasan yang tinggi, sehingga seseorang cenderung menunda tugas tersebut.

Hal tersebut dikarenakan menganggap bahwa tugas yang diberikan dari sekolahnya harus 
benar dan sempurna sehingga mereka bisa mendapat nilai yang baik. Akan tetapi, responden merasa cemas untuk tidak dapat menjawab tugas atau tidak memperoleh nilai yang baik sehingga mereka cenderung melakukan prokastinasi akademiknya. Selain itu, para responden juga merasa tugasnya akan dikerjakan secara tidak maksimal karena terkejar oleh deadline yang diberikan oleh gurunya sehingga menimbulkan kecemasan sepanjang waktu pengerjaan tugas, sehingga jumlah kesalahan tinggi karena individu mengerjkakan dalam waktu yang sempit. Disamping itu, sulit berkonsentrasi karena ada perasaan cemas sehingga motivasi belajar dan kepercayaan diri mereka menjadi sangat rendah dalam melakukan tugasnya.

\section{Dukungan Sosial}

Faktor ketujuh yang menyebabkan siswa yang mengikuti OSIS melakukan prokrastinasi dalam melaksanakan tugas sekolahnya yaitu Dukungan Sosial. Dukungan sosial merupakan faktor eksernal yang mempengaruhi siswa yang mengikuti kegiatan OSIS dalam melakukan prokrastinasi Akademiknya. Hal ini bertolak belakang dengan teori (Mustakim, 2015) yang menyatakan bahwa dukungan sosial merupakan bentuk dorongan yang dilakukan oleh lingkungan sosial yang dalam bentuk nasihat verbal atau nonverbal yang memberikan manfaat emosional atau efek perilaku bagi individu sebagai makhluk sosial.

Dukungan sosial yang diberi oleh keluarga, saudara, teman maupun kekasih yang mereka miliki bukan merupakan suatu pengaruh yang membuat mereka melakukan prokrastinasi akademiknya. Bagi mereka justru itu sebagai pemacu mereka untuk terus berusaha dalam melaksanakan tugasnya. Mereka beranggapan bahwa masa depan yang cerah dari dirinya tentunya berasal dari dukungan dari orang-orang terdekatnya, sehingga sulit baginya untuk melakukan prokrastinasi akademik jika mengingat hal tersebut. Dengan adanya bimbingan, arahan, masukan, serta dukungan dari orang lain akan membuat siswa yang mengikuti kegiatan OSIS semakin semangat untuk mengerjakan tugas yang diberikan oleh gurunya, terlebih lagi setelah aktivitas kegiatan sekolah mereka selesai.

\section{Gaya Pengasuhan Orang Tua}

Faktor kedelapan yang menyebabkan siswa yang mengikuti OSIS melakukan prokrastinasi dalam melaksanakan tugas sekolahnya yaitu Gaya Pengasuhan Orang Tua. Gaya pengasuhan orang tua mrupakan faktor eksternal yang mempengaruhi prokrastinasi akademik. Hal tersebut bertolak belakang dengan teori (Ghufron \& Risnawita, 2010) bahwa tingkat pengasuhan otoriter ayah menyebabkan munculnya kecenderungan perilaku prokrastinasi yang kronis pada subjek penelitian anak, sedangkan tingkat pengasuhan demokratis ayah menghasilkan anak yang bukan prokrastinator. Ibu yang memiliki kecenderungan melakukan avoidance procrastination menghasilkan anak yang memiliki kecenderungan untuk melakukan avoidance procrastination pula.

Apa yang telah diajarkan oleh orang tua mereka kepada dirinya sudah baik dan mereka selalu mau menuruti apa keinginan orang tuanya tersebut. Bagi mereka, gaya pengasuhan orang tua tidak mempengaruhi mereka untuk melakukan prokrastinasi Orang tua mereka yang otoriter maupun demokratis tidak mempengaruhi mereka dalam melakukan prokrastinasi. Mereka cenderung tidak membawa masalah keluarga dalam menyelesaikan tugas yang diberikan. Asuhan maupun bimbingan dari orang tua mereka merupakan semangat bagi mereka untuk menggapai apa yang telah mereka cita-citakan, sehingga berat bagi mereka melakukan prokrastinasi jika mengingat hal tersebut.

\section{Hostility With Other}

Faktor kesembilan yang menyebabkan siswa yang mengikuti OSIS melakukan prokrastinasi dalam melaksanakan tugas sekolahnya yaitu Hostility With Other.Hostility with Other merupakan faktor eksternal yang mempengaruhi prokrastinasi akademik Hasil ini dapat dilihat dengan skor rangking yang dimiliki sebesar 384 dengan persentase 15,51 atau dapat dibulatkan menjadi 16\%. Hal tersebut bertolak belakang dengan (Catrunada, 2008) yang menyatakan bahwa Kemarahan terus menerus dapat menimbulkan dendam sikap bermusuhan sehingga bisa nenuju sikap menolak atau menentang apapun yang dikatakan orang tersebut.

Mereka jarang memiliki musuh baik dilingkungan rumah maupun dilingkungan sekolahnya. Kemarahan pada dirinya tidak sampai 
menimbulkan atau melupakan tugas yang telah diberikan kepada dirinya. Kemarahan yang ditimbulkan kepada dirinya tidak sampai menimbulkan permusuhan dengan orang lain. Apabila mereka memiliki musuh dengan orang lain, mereka akan segera dapat menyelesaikan masalahnya tersebut dengan cara perdamaian sehingga kedepan tidak lagi melakukan hal yang sama. Bagi responden, jika mereka pun mempunyai musuh baik di lingkungan rumah maupun di lingkungan sekolah mereka cenderung tidak membawa masalah tersebut dalam tugasnya. Selain itu, dalam mengerjakan tugasnya, siswa yang mengikuti kegiatan OSIS tidak selalu bergantung pada orang lain. Dengan kata lain, permusuhan yang terjadi dengan orang lain tidak akan berpengaruh terhadap responden untuk melakukan prokrastinasi akademiknya.

\section{Kondisi Lingkungan}

Faktor kesepuluh yang menyebabkan siswa yang mengikuti OSIS melakukan prokrastinasi dalam melaksanakan tugas sekolahnya yaitu Kondisi Lingkungan. Kondisi lingkungan merupakan faktor eksternal yang mempengaruhi prokrastinasi akademik Hal ini bertolak belakang dengan teori (Catrunada, 2008) yang menyatakan bahwa Tidak teraturnya lingkungan bisa dalam bentuk interupsi dari orang lain, kurangnya privasi, kertas yang bertebaran dimana-mana, dan alat-alat yang dibutuhkan dalam pekerjaan tersebut tidak tersedia. Adanya begitu banyak gangguan pada areal pekerjaan menyulitkan seseorang untuk berkonsentrasi sehingga pekerjaan tersebut tidak bisa diselesaikan tepat pada waktunya. Kondisi lingkungan baik di sekolah maupun di luar sekolah tempat tinggal tinggalnya sangat baik. Kondisi lingkungan tempat tinggal responden dapat dikatakan sangat mendukung dalam hal pengerjaan tugasnya karena mereka sejauh ini masih merasa nyaman dan aman pada tempat tinggalnya tersebut. Selain itu, kondisi sekolah juga tidak jauh berbeda, mereka memiliki guru yang terampil dan pandai di bidangnya masing-masing. Peraturan di sekolah juga mengharuskan mereka untuk menyelesaikan tugas mereka secara baik. Apabila tidak dikerjakan, mereka tentunya akan mendapatkan hukuman dari sekolahnya tersebut yang juga akan berpengaruh terhadap nilai yang akan didapatnya nanti ketika pembagian raport. Dengan kondisi lingkungan yang seperti ini, responden merasa berat untuk melakukan prokrastinasi akademiknya.

\section{SIMPULAN}

Prokrastinasi yang dilakukan oleh siswa banyak terjadi di sekolah. Prokrastinasi identik dengan bentuk kemalasan dan keterlambatan setiap orang baik orang tua maupun muda dan juga seorang pengangguran juga dapat menjadi seorang prokrastinator karena prokrastinasi tidak membeda-bedakan umur, ras, kepercayaan, jenis kelamin serta suku bangsa. Seseorang yang melakukan prokrastinasi dapat dikatakan sebagai salah satu perilaku yang tidak efisien dalam penggunaan waktu dan cenderung untuk tidak segera memulai suatu kerja ketika menghadapi suatu tugas. Prokrastinasi dapat dipandang dari berbagai segi karena prokrastinasi ini melibatkan suatu unsur masalah yang kompleks antara satu dengan yang lainnya. Jika dikaitkan dengan kegiatan belajar, siswa akan berusaha untuk mendekatkan pada hal-hal yang menyenangkan. Orang yang memiliki berbagai kegiatan juga biasanya cenderung akan menunda pekerjaannya dalam melaksanakan tugasnya. Akan tetapi setiap orang memiliki cara yang berbeda mengenai kegiatannya yang banyak tersebut sehingga kegiatannya tersebut ada yang berdampak positif atau negatif. Urutan faktor yang mempengaruhi prokrastinasi akademik pada siswa yang menjadi anggota OSIS yaitu Time Disorganisation, Keadaan Fisik Individu, Karakteristik Tugas, Sikap Dan Keyakinan, Kondisi Psikologis Individu, Anxiety, Dukungan Sosial, Gaya Pengasuhan Orang Tua, Hostility With Other, dan Kondisi Lingkungan.

\section{DAFTAR PUSTAKA}

Akinsola, T. \& Tella. (2007). Correlates of Academic Procrastination and Mathematics Achievement of University Undergraduate Student. Eurasia Journal of Mathematics, Science \& Technology Education, 2007, 3 (4), 363-367.

Arikunto, S. (1993). Prosedur Penelitian Suatu Pendekatan Praktik. Edisi Revisi II. Jakarta: Rineka Cipta.

Catrunada, L. (2008). Perbedaan Kecenderungan Prokrastinasi Tugas Skripsi Berdasarkan Tipe Kepribadian Introvert Dan Ekstovert. Skripsi. Fakultas Psikologi Universitas Gunadarma.

Djamarah, S.B. (2002). Bahasa sukses belajar. Jakarta: PT Rineka Cipta. 
Ferrari, J.R., Jhonson, J.L., \& McCown, W.G. (1995). Procrastination And Task Avoidance: Theory, Research and Treatment. New York: Plenum Press.

Fiore, N.A. (2006). The now habit: A strategic program for overcoming procrastination an enjoying guilt free play. New York: Penguin Group.

Ghufron, M. Nur. \& Risnawita, Rini, S. (2010). Teori-Teori Psikologi. Yogyakarta: Ar-Ruzz Media.

Hurlock, E.B. (1980). Psikologi Perkembangan Suatu Pendekatan Sepanjang Rentang Kehidupan Edisi Kelima. Jakarta: Erlangga.

LaForge, Mary, C. (2005). Applying Explanatory Style to Academi Procrastination. Clemson University.

L.J.Solomon \& E.D. Rothblum. (1984). Academic Procrastination: Frequency and Cognitive Behavioral Correlates. Journal of Counseling Psychology, 31.
Lubis, H. (2013). Studi Identifikasi Faktor Kecemasan Belum Menikah Pada Wanita Dewasa Di Kelurahan Panyabungan II Kabupaten Mandailing Natal. Skripsi. Universitas Medan Area. Sumatera Utara.

Mustakim. (2015). Hubungan Antara Locus Of Control Dengan Prokrastinasi Akademik Pada Siswa MAN 1 Medan. Skripsi. Universitas Medan Area. Sumatera Utara.

Rizki, S.A. (2009). Hubungan Prokrastinasi Akademis Dan Kecurangan Akademis Pada Mahasiswa Fakultas Psikologi Universitas Sumatera Utara. Skripsi. Sumatera Utara.

Ursia, Nela, Regar, Ide Bagus Siaputra, \& Nadia Sutanto. (2013). Prokrastinasi Akademik dan SelfControl pada Mahasiswa Skripsi Fakultas Psikologi Universitas Surabaya. Jurnal. Vol. 1798, No.17. 